\title{
Surface Density of Major Outer Membrane Proteins in Salmonella typhimurium in Different Growth Conditions
}

\author{
By MARTI ALDEA, ENRIQUE HERRERO,* M. ISABEL ESTEVE \\ AND RICARDO GUERRERO \\ Department of Microbiology and Institute of Fundamental Biology, \\ Autonomous University of Barcelona, Bellaterra, Barcelona, Spain
}

(Received 30 November 1979; revised 11 March 1980)

\begin{abstract}
The amount of major proteins per unit of surface area in the outer membrane (OM) of Salmonella typhimurium LT2 remained constant during steady-state growth in different media. Between growth rates of 2.40 doublings $h^{-1}$ and 0.31 doublings $h^{-1}$, the surface density of major OM proteins varied between $0.9 \times 10^{5}$ and $1.2 \times 10^{5}$ molecules per $\mu \mathrm{m}^{2}$, while surface area per cell more than halved. The accumulation of molecules of the major OM proteins was not affected by addition of cyclic AMP to the growth medium. When exponentially growing cells were subjected to shift-up transitions, cell dimensions began to increase after a lag period of $20 \mathrm{~min}$. Accumulation of major OM proteins followed the same pattern as total protein; this created a transitory imbalance of major OM protein density in the shift from acetate minimal medium to LB medium, before the steady situation was reached. After shift-down transitions, cell dimensions began to decrease immediately, cells eventually becoming shorter than in steady-state conditions. No fluctuations in major OM protein density were observed during the shift-down, although final stable levels differed from those in steady-state conditions. All these results indicate that bacteria adapt the accumulation of major proteins into the OM according to the amount of surface. Thus, no large differences exist at different cell sizes, although transitions between media can lead to transitory or stable changes in the composition of the OM.
\end{abstract}

\section{INTRODUCTION}

The outer membrane (OM) of Gram-negative bacteria contains at least 20 different polypeptides, as resolved by sodium dodecyl sulphate-polyacrylamide gel electrophoresis (SDS-PAGE) (Schnaitman, 1970; Ames et al., 1974; Kamio \& Nikaido, 1977; DiRienzo et al., 1978), while the number of types of protein in the whole envelope has been estimated as about 150 by two-dimensional gel electrophoresis (Ames \& Nikaido, 1976). Four or five of the OM proteins (OMP) of Escherichia coli are present in rather higher amounts than the others, so they are called 'major proteins' (Schnaitman, 1970; DiRienzo et al., 1978). Some of these major OMP of E. coli are peptidoglycan-associated and have been alternatively named matrix protein (Rosenbusch, 1974), proteins 1a and 1b (Bassford et al., 1977), proteins Ia and Ib (Schmitges \& Henning, 1976), proteins b and c (Lugtenberg et al., 1975) and porins (Kamio \& Nikaido, 1977). Studies with cross-linking agents have revealed the close spatial association between at least some molecules of porins (Palva, 1979), supporting previous observations with the electron microscope which indicated that porins were arranged as trimers with a central pore (Steven et al., 1977). Proteins b and c of $E$. coli K12 are biochemically different (Henning et al., 1977; Lee et al., 1979), although they 
seem to be commonly regulated by the product of the $o m p B$ gene (Verhoeff et al., 1979). With the usual SDS-PAGE methods, porins appear in Salmonella typhimurium in three bands at the region 34 to 36 kilodaltons (Ames et al., 1974; Kamio \& Nikaido, 1977; Gmeiner \& Schlecht, 1979) and their role in the penetration of the OM by hydrophilic molecules smaller than 600 daltons has been demonstrated (Decad \& Nikaido, 1976; Nakae, 1976). The 35 kilodalton protein of $S$. typhimurium is similar to protein b of $E$. coli K12 (Sato \& Yura, 1979). In addition, Salmonella OM contains another major protein of 33 kilodaltons, although no pore activity has been clearly demonstrated for it.

During the cell cycle of $E$. coli $\mathrm{B} / \mathrm{r}$ porins are synthesized at a constant rate, with a doubling of the rate $10 \mathrm{~min}$ before division (Boyd \& Holland, 1979). However, very little is known about the factors regulating the synthesis of porins and other major proteins of the OM. Culture conditions such as the richness of the medium, temperature and salt concentration influence the relative amounts of the major proteins (Lugtenberg et al., 1976; van Alphen \& Lugtenberg, 1977), but few data exist about the total amounts present at different growth conditions. The level of another major protein, $\mathrm{II}^{*}$, in the OM of E. coli $\mathrm{K} 12$ seems to be regulated by a feedback mechanism since partial diploids involving the gene $\operatorname{omp} A$, which codes for protein II* (Henning et al., 1976; Manning et al., 1976), do not show any gene dosage effect (Datta et al., 1976). This mechanism regulating the incorporation of OMP into the envelope could simply be determined by the amount of surface available for occupation by these proteins (Lugtenberg et al., 1976; Boyd \& Holland, 1979). If this is correct, the amount of the major OMP per unit of cell area would be expected to remain constant independently of the growth rate.

The above prediction can be tested by transferring bacteria from one growth medium to another, in so-called shift experiments. Such studies have previously shown that bacterial size is dependent upon the richness of the medium, in such a way that cell length and width increase as the growth rate increases (Schaechter et al., 1958; Donachie et al., 1976; Grover et al., 1977; Pierucci, 1978; Rosenberger et al., 1978). Therefore, when bacteria are transferred from poorer to richer media (shift-up) or from richer to poorer media (shift-down), cell dimensions change to adapt to the new conditions (Maaløe \& Kjeldgaard, 1966; Sloan \& Urban, 1976; Loeb et al., 1978). After a shift-up transition, cell division continues at the former rate for some time, while the rate of synthesis of biomass increases almost immediately to that characteristic of the new conditions (Maaløe \& Kjeldgaard, 1966; Loeb et al., 1978). This leads to the immediate increase of cell size, probably both in length and width. However, some strains of $E$. coli have been shown to behave in a more complex way, particularly during drastic changes of media. In these conditions, slowing (Loeb et al., 1978) or acceleration (Sloan \& Urban, 1976) of cell division can occur after the transition. Shiftdown transitions lead to an immediate reduction of the rate of accumulation of biomass, which in some strains can stop completely for a period. The rate of division is affected only after some time in the new medium. Consequently, the average cell size diminishes immediately after the shift-down transition (Maaløe \& Kjeldgaard, 1966).

In this paper we report on cell dimensions, both length and diameter, and on the amount of major OMP per unit of surface area when $S$. typhimurium LT2 grows in steady-state conditions and when it is subjected to shift-up and shift-down treatments, in order to investigate the control of OMP synthesis and assembly. Results indicate that the surface density of major OMP changes only slightly during different growth conditions that cause large differences in cell dimensions.

\section{METHODS}

Bacteria, growth conditions and culture transitions. Wild-type Salmonella typhimurium LT2, obtained from the collection of the Department of Microbiology of the University of California in Davis, was employed. Bacteria were grown at $37^{\circ} \mathrm{C}$ in $\mathrm{LB}$ medium or in minimal AB medium (Clark \& Maaløe, 1967) supplemented with a source of carbon. As carbon sources, glucose was added at $0.2 \%(w / v)$ and glycerol, 
sodium acetate or L-alanine at $0.4 \%(\mathrm{w} / \mathrm{v})$. Amino acids were added at $25 \mu \mathrm{g} \mathrm{ml}^{-1}$, vitamins at $2 \mu \mathrm{g} \mathrm{ml}^{-1}$ and casein hydrolysate at $0.4 \%(\mathrm{w} / \mathrm{v})$. In order to obtain steady-state conditions of growth, all bacterial cultures were grown exponentially for at least four generations before beginning the experiments. When necessary, bacteria were diluted in the same prewarmed medium to keep the culture density less than $10^{8} \mathrm{cells}^{-1}$ during the experiments. Growth kinetics were monitored by measuring the absorbance of the culture (at $550 \mathrm{~nm}$ for cultures in LB medium and at $450 \mathrm{~nm}$ for minimal medium), using a Beckman spectrophotometer, model DU-2 (1 cm light path). The total number of bacteria was determined with a PetroffHauser counter, from samples fixed in $0 \cdot 2 \%(\mathrm{v} / \mathrm{v})$ formaldehyde at $0{ }^{\circ} \mathrm{C}$.

Culture transitions were carried out by filtering $150 \mathrm{ml}$ of exponentially grown bacteria at a concentration of $3 \times 10^{7}$ to $5 \times 10^{7}$ cells $\mathrm{ml}^{-1}$ using a Sartorius membrane filter (pore size $0.45 \mu \mathrm{m}$ ), washing the filter with $50 \mathrm{ml}$ of the new medium prewarmed at $37^{\circ} \mathrm{C}$ and transferring it to a flask containing $150 \mathrm{ml}$ of the new medium at $37^{\circ} \mathrm{C}$. The whole operation was completed in no more than $3 \mathrm{~min}$.

Electrophoresis of total cell proteins in SDS-polyacrylamide slab gels. Samples were taken from the cultures and $\mathrm{KCN}$ was added to a final concentration of $2 \mathrm{~mm}$. Bacteria were washed with $50 \mathrm{~mm}-\mathrm{Tris} / \mathrm{HCl} \mathrm{pH} 6 \cdot 8$ at $0{ }^{\circ} \mathrm{C}$ and resuspended in the same buffer at $0{ }^{\circ} \mathrm{C}$ to obtain a final protein concentration of 3 to $5 \mathrm{mg} \mathrm{ml}^{-1}$. This suspension could be kept at $-20^{\circ} \mathrm{C}$ for at least 2 months. Proteins from the washed organisms were solubilized by boiling them for $2 \mathrm{~min}$ in a solution containing $2 \%(\mathrm{w} / \mathrm{v}) \mathrm{SDS}, 5 \%(\mathrm{v} / \mathrm{v})$ mercaptoethanol, $10 \mathrm{~mm}$-EDTA, $0.015 \%(\mathrm{w} / \mathrm{v})$ Bromophenol Blue and $5 \%(\mathrm{w} / \mathrm{v})$ glycerol in $0.5 \mathrm{M}-\mathrm{Tris} / \mathrm{HCl} \mathrm{pH}$ 6.8. Samples (10 $\mathrm{l}$, corresponding to about $20 \mu \mathrm{g}$ protein) were then applied to each slot of an SDS-polyacrylamide gel. Preparation of the gels and buffer system were as described by Laemmli (1970). The concentration of the stacking gel was $5 \%(\mathrm{w} / \mathrm{v})$ acrylamide and $0 \cdot 15 \%(\mathrm{w} / \mathrm{v})$ bisacrylamide, while that of the separating gel was $10 \%$ acrylamide and $0.3 \%$ bisacrylamide. Electrophoresis was carried out at a constant current of $15 \mathrm{~mA}$ through the stacking gel and $30 \mathrm{~mA}$ through the separating gel. Gels were stained for $1 \mathrm{~h}$ in a solution of $0.05 \%(\mathrm{w} / \mathrm{v})$ Coomassie Blue in $25 \%(\mathrm{v} / \mathrm{v})$ isopropyl alcohol plus $10 \%(\mathrm{v} / \mathrm{v})$ acetic acid. Destaining was done by three successive washings for $1 \mathrm{~h}$ periods in the following solutions: (i) $0.005 \%$ Coomassie Blue in $10 \%$ isopropyl alcohol plus $10 \%$ acetic acid, (ii) $0.0025 \%$ Coomassie Blue in $10 \%$ acetic acid and (iii) $10 \%$ acetic acid. Stained gels were scanned using a Pye Unicam densitometer, model SP1809, and the relative areas under the peaks corresponding to the proteins being studied were measured. Absolute amounts of individual proteins per cell were calculated considering the relative areas of the peaks and the value of total protein per cell. Protein concentration was calculated by the Lowry method, using a $50 \mathrm{~mm}-\mathrm{Tris} / \mathrm{HCl}$ pH 6.8 solution as standard.

In all the electrophoresis experiments the following molecular weight standards were run in parallel: bovine pancreatic RNAase (12500), egg white lysozyme (14000), human $\gamma$-globulin L (21 500), ovalbumin (43000), human $\gamma$-globulin $H(50000)$ and bovine serum albumin (68000).

Fractionation of cells and protein analysis of fractions. About $2 \times 10^{10}$ bacteria were resuspended in $2 \mathrm{ml}$ of ice-cold $10 \mathrm{~mm}$-Tris/ $\mathrm{HCl} \mathrm{pH} 7.8$ containing $0.75 \mathrm{M}$-sucrose. Lysozyme was added to a final concentration of $0.5 \mathrm{mg} \mathrm{ml}^{-1}$ and, after $3 \mathrm{~min}$ on ice, EDTA was added dropwise to a final concentration of $5 \mathrm{~mm}$. The suspension was incubated on ice for $2 \mathrm{~h}$ with stirring and the resulting spheroplasts were lysed by addition of 3 vol. of cold distilled water. Unbroken cells were removed by low speed centrifugation and the supernatant was again centrifuged $(48000 \mathrm{~g}, 1 \mathrm{~h})$. The resulting supernatant was kept as the fraction containing cytoplasmic proteins, while the envelope pellet was washed once in $50 \mathrm{~mm}-\mathrm{Tris} / \mathrm{HCl} \mathrm{pH} 6.8$ and separated into inner and outer membrane fractions by treatment with Sarkosyl NL97 at $0.5 \%$ (w/v) in a final volume of $100 \mu \mathrm{l}$ (Filip et al., 1973). After $30 \mathrm{~min}$ incubation at room temperature inner membrane proteins were solubilized, while outer membranes remained insoluble and were subsequently sedimented by centrifugation at $9^{\circ} \mathrm{C}(48000 \mathrm{~g}, 2 \mathrm{~h})$. The outer membrane pellet was resuspended in $100 \mu \mathrm{l} 50 \mathrm{~mm}$-Tris/ $\mathrm{HCl} \mathrm{pH}$ 6.8. Proteins from the different fractions were analysed by SDS-PAGE, using the method described above for total cell lysates.

Measurement of cell dimensions. Samples $(2 \mathrm{ml})$ from the cultures were fixed with formaldehyde at a final concentration of $2 \%(\mathrm{v} / \mathrm{v})$ and kept at $0{ }^{\circ} \mathrm{C}$ for $1 \mathrm{~h}$. They were washed with $0.2 \%$ formaldehyde $(5 \mathrm{ml})$ and resuspended in $10 \mu \mathrm{l}$ of the same solution. A small drop of the suspension was placed on a Formvar film, allowed to dry, stained with $1 \%(\mathrm{w} / \mathrm{v})$ phosphotungstic acid and the bacteria were observed with a Hitachi electron microscope, model HU-12A, with an enlargement of 3000 . Electron micrographs were taken and the measurement of cell dimensions (length and diameter) was done on the corresponding prints with a final enlargement of 10000 . At least 100 cells from each sample were measured. In order to calculate surface area and volume, bacteria were considered as rods with two hemispherical caps.

Chemicals. Sugars, amino acids, vitamins and inorganic chemicals were obtained from Merck. Casein hydrolysate was from Oxoid, acrylamide was from Cambrian Chemicals and bisacrylamide from Eastman Kodak. 


\section{Table 1. Cell dimensions of $S$. typhimurium LT2 at different growth rates}

Media used were as follows. 1: LB medium. 2: AB medium plus casein hydrolysate $(0.4 \%, \mathrm{w} / \mathrm{v})$, glucose $(0.2 \%, \mathrm{w} / \mathrm{v})$, tryptophan $\left(25 \mu \mathrm{g} \mathrm{ml}^{-1}\right)$, adenine, cytosine, guanine, uracil and thymidine (each $20 \mu \mathrm{g} \mathrm{ml}^{-1}$ ) and thiamin and biotin (each $2 \mu \mathrm{g} \mathrm{ml}^{-1}$ ). 3: AB medium plus casein hydrolysate $(0.4 \%, \mathrm{w} / \mathrm{v})$, glucose $(0 \cdot 2 \%, \mathrm{w} / \mathrm{v})$ and tryptophan $\left(25 \mu \mathrm{g} \mathrm{ml}^{-1}\right) .4: \mathrm{AB}$ medium plus glucose $(0.2 \%, \mathrm{w} / \mathrm{v})$ and methionine, histidine, arginine, proline, threonine and tryptophan (each $25 \mu \mathrm{g}$ $\left.\mathrm{ml}^{-1}\right)$. 5: AB medium plus glucose $(0.2 \%, \mathrm{w} / \mathrm{v})$. 6: AB medium plus glycerol $(0.4 \%, \mathrm{w} / \mathrm{v})$. $7: \mathrm{AB}$ medium plus sodium acetate $(0.4 \%, w / v)$. 8: AB medium plus L-alanine $(0.4 \%, w / v)$.

All values are means of at least two different experiments, the values of individual experiments being represented in Fig. 1(a). Values of length and diameter are the average of at least 100 cells measured in each experiment. The numbers in the parentheses correspond to the standard deviation.

$\begin{array}{ccccccc}\text { Medium } & \begin{array}{c}\text { Doubling } \\ \text { rate } \\ \left(\mathrm{h}^{-1}\right)\end{array} & \begin{array}{c}A_{450} \\ \text { per 10 } \\ \text { cells }\end{array} & \begin{array}{c}\text { Length } \\ (\mu \mathrm{m})\end{array} & \begin{array}{c}\text { Diameter } \\ (\mu \mathrm{m})\end{array} & \begin{array}{c}\text { Surface } \\ \text { area } \\ \left(\mu \mathrm{m}^{2}\right)\end{array} & \begin{array}{c}\text { Volume } \\ \left(\mu \mathrm{m}^{3}\right)\end{array} \\ 1 & 2.40 & 4.06 & 2.80(0.727) & 0.731(0.054) & 6.43 & 1.073 \\ 2 & 2.18 & 3.52 & 2.69(0.702) & 0.676(0.051) & 5.71 & 0.885 \\ 3 & 1.85 & 3.27 & 2.60(0.676) & 0.650(0.049) & 5.31 & 0.791 \\ 4 & 1.60 & 2.44 & 2.52(0.597) & 0.598(0.039) & 4.73 & 0.651 \\ 5 & 1.15 & 1.91 & 2.31(0.514) & 0.581(0.039) & 4.21 & 0.560 \\ 6 & 0.77 & 1.25 & 2.06(0.464) & 0.546(0.041) & 3.54 & 0.441 \\ 7 & 0.56 & 1.07 & 1.80(0.433) & 0.528(0.035) & 2.98 & 0.355 \\ 8 & 0.31 & 0.88 & 1.82(0.417) & 0.507(0.031) & 2.90 & 0.334\end{array}$

\section{RESULTS}

Cell dimensions and amount of major OMP in exponentially growing S. typhimurium LT2

The dependence of cell length and diameter on the growth rate in $S$. typhimurium LT2 was studied. Exponentially growing cells were both longer and wider in rich media than in poorer media, in the eightfold range of growth rates studied (Table 1). This confirmed results previously obtained by others with several strains of $S$. typhimurium and $E$. coli (Schaechter et al., 1958; Donachie et al., 1976; Grover et al., 1977; Pierucci, 1978; Rosenberger et al., 1978). In Fig. 1(a) cell size, measured both as the real cell volume and as the index of $A_{450}$ per $10^{9}$ cells, is plotted against the doubling rate. Each point corresponds to a different growth experiment. It can be seen that both size parameters are directly proportional to the growth rate and that the proportionality constant is approximately the same for both. That is, the ratio of $A_{450}$ per unit of volume remains constant, independently of cell dimensions and, therefore, the absorbance seems to be a measure of cell volume. However, the variation of cell size with respect to growth rate in the strain studied here was less than that observed in other strains. Whilst at low growth rates the values indicated in Table 1 are similar to those reported for other bacteria, at higher growth rates the cells were not so large. Thus, we observed a near fourfold change in cell volume over the range from 0.31 to 2.40 doublings $\mathrm{h}^{-1}$, while other strains of $S$. typhimurium (Schaechter et al., 1958 ) or $E$. coli $\mathrm{B} / \mathrm{r}$ (Rosenberger et al., 1978) showed a five- to sevenfold change in volume over the same range of growth rates.

The amount of protein per cell in $S$. typhimurium LT2 also increased proportionally to growth rate in the whole range of conditions studied (Fig. $1 b$ ). However, whilst the amount of protein per unit of cell volume increased in proportion to growth rate at growth rates less than 1.5 doublings $\mathrm{h}^{-1}$, it remained constant at higher growth rates. This fact is in accordance with the observed constancy in the ratio protein/DNA (Maaløe \& Kjeldgaard, 1966; Dennis \& Bremer, 1974; Shen \& Bremer, 1977) and in the amount of DNA per unit of cell volume (Kubitschek, 1974) in rapidly growing bacteria.

The amount of major OMP per unit of surface area in cells growing in different media was next measured in order to determine if it was in any way dependent upon cell size and shape. Total cell proteins were analysed by SDS-PAGE and the relative area under the 

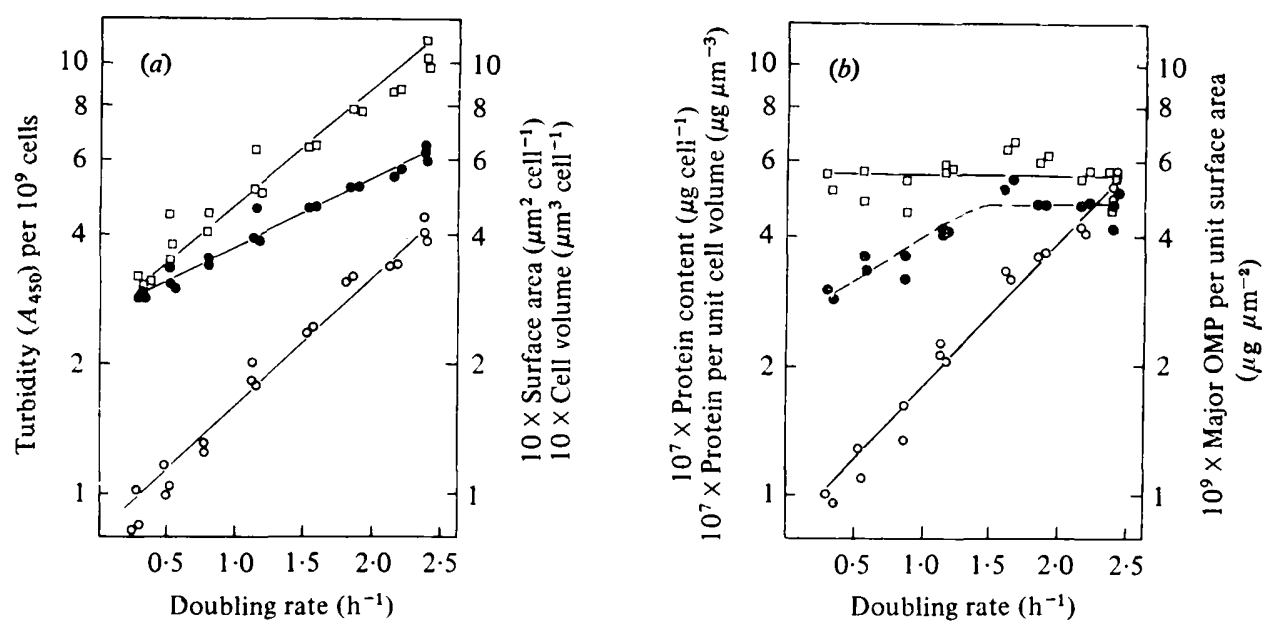

Fig. 1. Relationship between growth rate and several cellular properties in exponentially growing cells of Salmonella typhimurium LT2. Bacteria were grown exponentially at $37^{\circ} \mathrm{C}$ for more than four generations in the media indicated in the legend to Table 1. (a) $A_{450}$ per $10^{\circ}$ cells $(O)$, surface area (O) and cell volume ( $\square$ ). (To obtain the $A_{450}$ per $10^{9}$ cells from bacteria grown in LB medium, culture samples were fixed at $0^{\circ} \mathrm{C}$, filtered and resuspended in $\mathrm{AB}$ medium.) (b) Total protein per cell $(O)$, total protein per unit of cell volume (O) and major OMP per unit of surface area $(\square)$.

four peaks in the 33 to 36 kilodalton region was measured from gel scans and taken as the proportion of major OMP relative to total protein. This approximation could be justified because the major OMP appear to be amongst the most abundant proteins at different growth rates (Pedersen et al., 1978). Thus, any other band appearing in this region should constitute only a minor proportion. To confirm this, proteins from different cell fractions were analysed separately by SDS-PAGE. Figure 2 shows the gel scans from cells growing in minimal medium. Porins are described as 34 to $36 \mathrm{~K}$ and the 33000 kilodalton protein as $33 \mathrm{~K}$. Cytoplasmic proteins migrating in the 33 to $36 \mathrm{~K}$ region accounted for only $5 \%$ of those in total cell lysates. A minor amount of the 33, 34, 35 and $36 \mathrm{~K}$ proteins appeared in gels corresponding to inner membranes, due to the fact that Sarkosyl solubilizes a small proportion of OMP (Filip et al., 1973; Boyd \& Holland, 1979). However, two-dimensional gel electrophoresis confirmed that those minor peaks corresponded to the major OMP. Results from cells grown in other media were similar, therefore confirming that no less than $95 \%$ of the area under the peaks in the 33 to $36 \mathrm{~K}$ region is due to the four major OMP. In a second control, the relative area under the 33 to $36 \mathrm{~K}$ peaks was found to be independent of the concentration of protein in the solubilization mixture in the range 0.5 to $3.5 \mu \mathrm{g}$ protein $\mu \mathrm{l}^{-1}$, indicating that solubilization of major OMP by SDS was not influenced by the amount of total protein.

As indicated in Table 2, the proportion of major OMP with respect to total protein was lower in rich media than in poorer media. However, the density of the four major OMP per unit of surface area did not significantly change in the different growth conditions (Fig. $1 b$ and Table 2 ). When the porins and the $33 \mathrm{~K}$ protein were analysed separately, the ratio of one to the other did not change over the whole range of growth rates tested, porins representing about $45 \%$ of the major OMP (Table 2). The results obtained correspond to $0.9 \times 10^{5}$ to $1.2 \times 10^{5}$ molecules of major proteins per $\mu \mathrm{m}^{2}$ of OM. It has been proposed that lipopolysaccharide molecules are associated with porin molecules in the OM (DiRienzo et al., 1978). The number of lipopolysaccharide molecules per $\mu \mathrm{m}^{2}$ of $\mathrm{OM}$ has been reported as $3.5 \times 10^{5}$ (Smit et al., 1975; Nikaido \& Nakae, 1979), that is, about eight times that of porins reported here. The lack of dependence of the amount of porins on growth rate is in accordance with results obtained recently with E. coli B/r (Boyd \& Holland, 1979). 


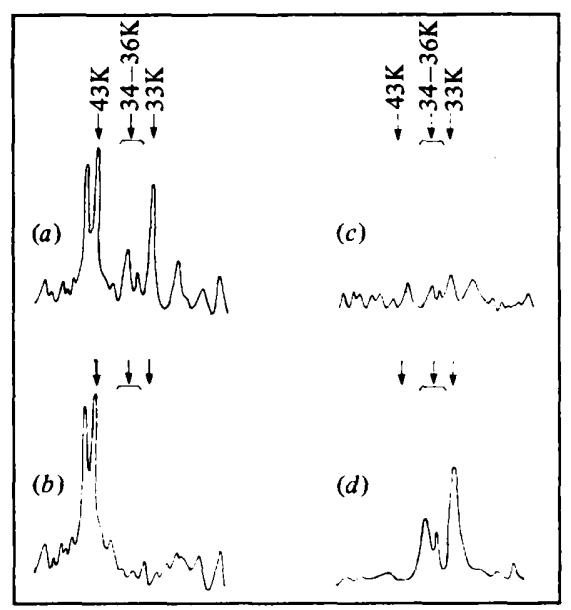

Fig. 2. Scans of proteins from different fractions of $S$. typhimurium LT2 cells grown in glucose minimal medium at $37^{\circ} \mathrm{C}$. Proteins were subjected to SDS-PAGE and stained gels were scanned as described in the text. (a) Total cell lysates, $(b)$ cytoplasmic fraction, $(c)$ inner membranes and (d) outer membranes. The amount of protein loaded in each slot was obtained from a similar number of cells. Only the region of the gel where the major OMP migrated is represented; the $43 \mathrm{~K}$ peak corresponds to the EF-Tu protein.

\section{Table 2. Amount of total protein and major OMP in S. typhimurium LT2 at different growth rates}

Growth media are given in Table 1. Results are the mean of at least two different experiments and the values of individual experiments are represented in Fig. 1(b).

The protein per volume was calculated from the values of average cell volume (indicated in Table 1) and the amount of protein per cell. The proportion of individual proteins with respect to total protein was obtained as indicated in the text. The major OMP per surface area was calculated from the ratio of major OMP to total protein, the amount of protein per cell and the average cell surface.

\begin{tabular}{|c|c|c|c|c|c|c|c|}
\hline $\begin{array}{c}\text { Doubling } \\
\text { rate } \\
\left(\mathrm{h}^{-1}\right)\end{array}$ & $\begin{array}{c}10^{7} \times \text { Protein } \\
\text { per cell } \\
\left(\mu \text { cell }^{-1}\right)\end{array}$ & $\begin{array}{c}10^{7} \times \text { Protein } \\
\text { per volume } \\
\left(\mu \mathrm{g} \mu \mathrm{m}^{-3}\right)\end{array}$ & $\begin{array}{l}\text { Porins } \\
\text { per total } \\
\text { protein } \\
(\%)\end{array}$ & $\begin{array}{l}\text { 33K protein } \\
\text { per total } \\
\text { protein } \\
(\%)\end{array}$ & $\begin{array}{c}\text { Porins/ } \\
\text { Major OMP }\end{array}$ & $\begin{array}{l}\text { Major OMP } \\
\text { per total } \\
\text { protein } \\
(\%)\end{array}$ & $\begin{array}{l}10^{9} \times \text { Major } \\
\text { OMP per } \\
\text { surface area } \\
\left(\mu \mathrm{g} \mu \mathrm{m}^{-2}\right)\end{array}$ \\
\hline $2 \cdot 40$ & $5 \cdot 21$ & $4 \cdot 86$ & $3 \cdot 2$ & 3.4 & 0.49 & 6.6 & $5 \cdot 34$ \\
\hline $2 \cdot 18$ & $4 \cdot 34$ & 4.90 & $3 \cdot 1$ & $4 \cdot 3$ & 0.42 & $7 \cdot 4$ & $5 \cdot 58$ \\
\hline 1.85 & 3.84 & 4.85 & 3.6 & $4 \cdot 8$ & 0.43 & 8.4 & 6.07 \\
\hline 1.60 & 3.54 & 5.44 & 3.7 & $5 \cdot 3$ & 0.41 & $9 \cdot 0$ & 6.72 \\
\hline $1 \cdot 15$ & $2 \cdot 33$ & $4 \cdot 16$ & $4 \cdot 5$ & 6.2 & 0.42 & 10.7 & 5.84 \\
\hline 0.77 & 1.52 & 3.45 & $5 \cdot 8$ & 5.8 & 0.50 & 11.6 & $5 \cdot 00$ \\
\hline 0.56 & $1 \cdot 24$ & $3 \cdot 45$ & 5.8 & $7 \cdot 1$ & 0.45 & 12.9 & $5 \cdot 19$ \\
\hline 0.31 & 0.99 & $2 \cdot 97$ & 6.7 & $9 \cdot 0$ & 0.43 & 15.7 & $5 \cdot 33$ \\
\hline
\end{tabular}

Effect of cyclic AMP on the amount of major $O M P$

A catabolite repression effect on several OMP of $E$. coli has been observed (Aono et al., 1978; Alderman et al., 1979), although no results for major OMP have been described. Therefore, we considered the possibility that the level of major proteins in the OM in the different conditions of growth was regulated by cyclic AMP. However, no effect of catabolite repression on major OMP was observed, since cyclic AMP at $1 \mathrm{mM}$ did not alter the relative proportion of these proteins (Table 3), although bacteria grew more slowly and the total amount of protein per cell was reduced in the presence of cyclic AMP in both LB medium and minimal medium plus glucose. This latter effect was not observed in minimal medium plus acetate. 
Table 3. Effect of cyclic AMP on the relative amount of major OMP in $S$. typhimurium LT2 growing in different media

Results in the absence of cyclic AMP are the same as in Table 2.

\begin{tabular}{|c|c|c|c|c|c|c|}
\hline \multirow[b]{2}{*}{ Medium } & \multicolumn{3}{|c|}{ Without added cyclic AMP } & \multicolumn{3}{|c|}{ With 1 mM-cyclic AMP } \\
\hline & $\begin{array}{c}\text { Doubling } \\
\text { rate } \\
\left(\mathrm{h}^{-1}\right)\end{array}$ & $\begin{array}{c}10^{7} \times \text { Protein } \\
\text { per cell } \\
\left(\mu \mathrm{g} \mathrm{cell}{ }^{-1}\right)\end{array}$ & $\begin{array}{c}\text { Major OMP } \\
\text { per total } \\
\text { protein } \\
(\%)\end{array}$ & $\begin{array}{c}\text { Doubling } \\
\text { rate } \\
\left(h^{-1}\right)\end{array}$ & $\begin{array}{c}10^{7} \times \text { Protein } \\
\text { per cell } \\
\left(\mu \mathrm{g} \text { cell }{ }^{-1}\right)\end{array}$ & $\begin{array}{c}\text { Major OMP } \\
\text { per total } \\
\text { protein } \\
(\%)\end{array}$ \\
\hline LB & $2 \cdot 40$ & $5 \cdot 21$ & $6 \cdot 6$ & $2 \cdot 00$ & $4 \cdot 51$ & $6 \cdot 6$ \\
\hline AB plus glucose & $1 \cdot 15$ & $2 \cdot 33$ & $10 \cdot 7$ & 0.98 & $2 \cdot 12$ & $10 \cdot 6$ \\
\hline AB plus acetate & 0.56 & $1 \cdot 24$ & $12 \cdot 9$ & 0.55 & 1.42 & $12 \cdot 3$ \\
\hline
\end{tabular}

\section{Changes in major OMP surface density during a shift-up transition}

We next studied the effect of medium transitions on the amount of major OMP and the parallel changes in cell dimensions and, correspondingly, in surface area. As major OMP accumulation was not affected by catabolite repression we assumed that alterations in the former during a shift should be exclusively due to the mechanisms which regulate the accumulation of those proteins in the OM in relation to cell size.

Figure 3(a) shows the effect of a shift-up from minimal medium plus glucose (doubling time of 50 to $55 \mathrm{~min}$ ) to LB medium in $S$. typhimurium LT2. Absorbance began to increase immediately at higher growth rate than in the pre-shift medium, although the doubling time $(29 \mathrm{~min})$ throughout the experiment was slightly longer than in steady-state cultures (24 to $25 \mathrm{~min}$ ). Bremer \& Dennis (1975) have predicted - on a theoretical basis - a delay in the attainment of the steady-state conditions after a shift-up, but these were not reached in the shifts reported. Changes in cell number followed a more complex pattern, with a delay in the rate of cell division between 10 and $25 \mathrm{~min}$ after the shift. After this interval all the parameters increased in parallel.

Figure 3(b) shows the effect of a more drastic change from minimal medium plus acetate (doubling time of 105 to $115 \mathrm{~min}$ ) to LB medium. The pattern of changes in the different parameters was similar to that following the shift from glucose to LB medium, although the increase in absorbance did not immediately adjust to that equivalent to LB medium. During the first $50 \mathrm{~min}$ after the shift, the doubling time was $41 \mathrm{~min}$ and after that a doubling time of 29 min was achieved, still longer than that of steady-state conditions. Cell number increased during the first 10 min after the transfer, followed by a lag before resuming at a rate which paralleled absorbance. Both total protein and major OMP also showed a lag of 20 to $25 \mathrm{~min}$ in their accumulation, followed by a sharp increase until reaching an amount per cell close to that characteristic of the new medium.

Changes in cell dimensions in both shifts were followed by direct measurement of electron micrographs of cells from samples taken at different times. Figure 4(a) shows the changes in cell length and diameter during both shifts. It should be noted that cells became smaller immediately after the transfer, so cell dimensions at time 0 in Fig. 4 are not comparable with those of steady-state conditions in the original media; this change in cell dimensions after transfer has also been observed by Woldringh et al. (unpublished observations) in shift-up experiments not involving filtration and may be due to the effect of osmotic stress on the cells. Whereas in the acetate to LB medium shift 80 min were required to stabilize cell dimensions, in the glucose to LB medium shift no stabilization of these parameters was reached after $80 \mathrm{~min}$ from the transition. The most interesting result was that in each case length and diameter did not begin to increase immediately after the shift. There was a lag period of $20 \mathrm{~min}$ during which cell dimensions were those of the previous medium. This period coincided with the deceleration of cell division previously described (see Fig. 3). 


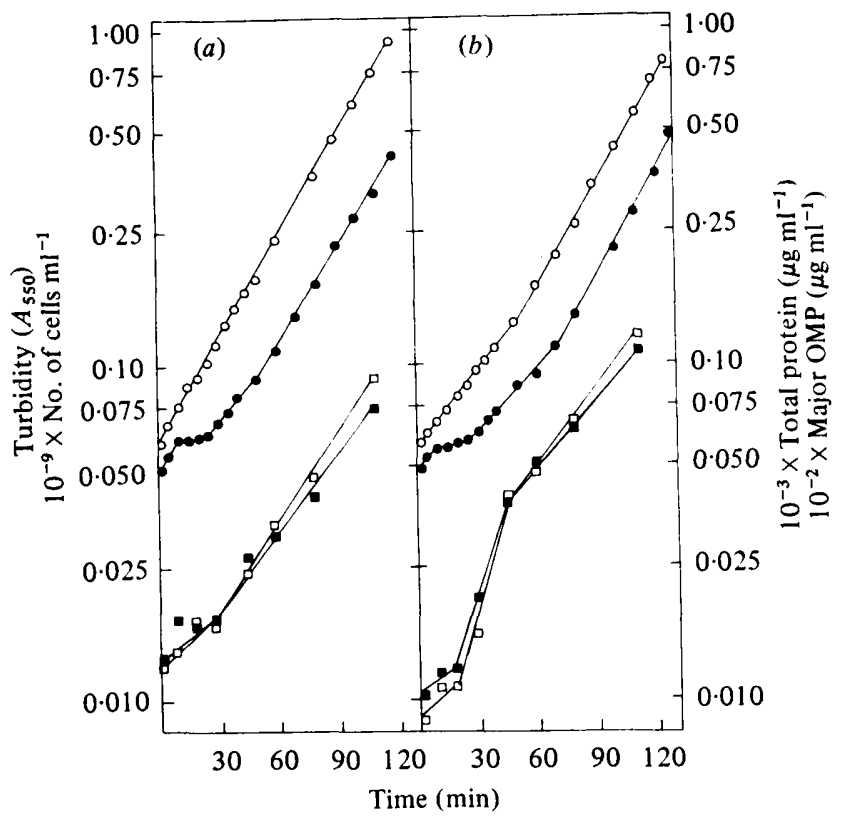

Fig. 3. Effect of shift-up transitions from (a) $\mathrm{AB}$ medium plus $0.2 \%$ (w/v) glucose, or $(b) \mathrm{AB}$ medium plus $0.4 \%(\mathrm{w} / \mathrm{v})$ acetate, to LB medium on the pattern of cell division and on the amount of total cell protein and major OMP. Salmonella typhimurium LT2 was grown exponentially at $37^{\circ} \mathrm{C}$ in the original medium to a density of about $5 \times 10^{7}$ bacteria ml-1; at time 0 , a sample of cells was filtered, washed with prewarmed LB medium and resuspended in the original volume of $\mathrm{LB}$ medium at $37^{\circ} \mathrm{C}$. At intervals, samples were taken from the culture and the following measurements were done: $A_{550}(\bigcirc)$, total number of cells per $\mathrm{ml}(\bullet)$, total cell protein per $\mathrm{ml}(\square)$ and major OMP per $\mathrm{ml}(\boldsymbol{\square})$.

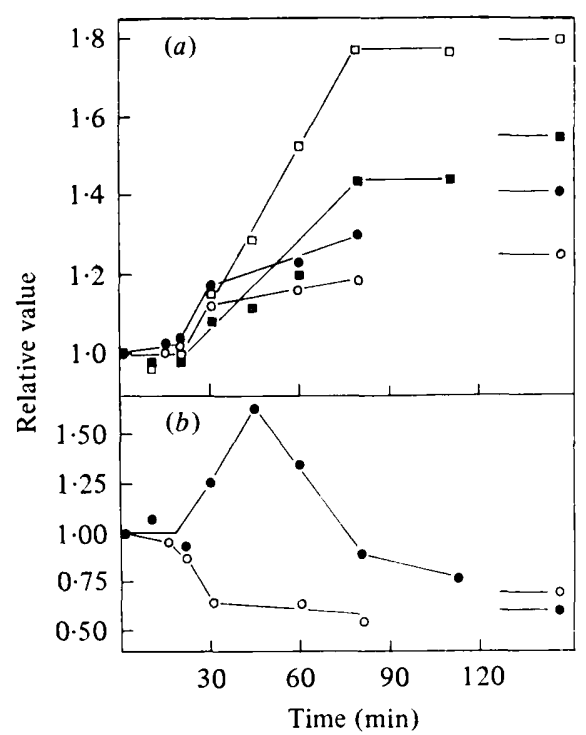

Fig. 4. (a) Changes in cell length $(O, \square)$ and diameter $(\boldsymbol{\bullet}, \mathbf{\square})$ after shift-up transitions of $S$. typhimurium LT2 from glucose minimal medium $(O, \bullet)$ or acetate minimal medium $(\square, \square)$ to LB medium. Transitions were done as described in the legend to Fig. 3. Relative values of 1.0 correspond to the following absolute values: $\bigcirc, 2.23 \mu \mathrm{m} ; 0,0.518 \mu \mathrm{m} ; \square, 1.56 \mu \mathrm{m} ; \mathbf{\square}, 0.464 \mu \mathrm{m}$. (b) Changes in the major OMP per unit of cell surface after shift-up transitions from glucose minimal medium $(O)$ or acetate minimal medium $(\bullet)$ to LB medium. Relative values of 1.0 correspond, respectively, to absolute values of $7.99 \times 10^{-9}$ and $9.07 \times 10^{-9} \mu \mathrm{g}$ major OMP per $\mu \mathrm{m}^{2}$ of cell surface. Bars with the corresponding symbols (on the right) indicate the levels of the different parameters in steady-state cultures in LB medium (see Tables 1 and 2). 


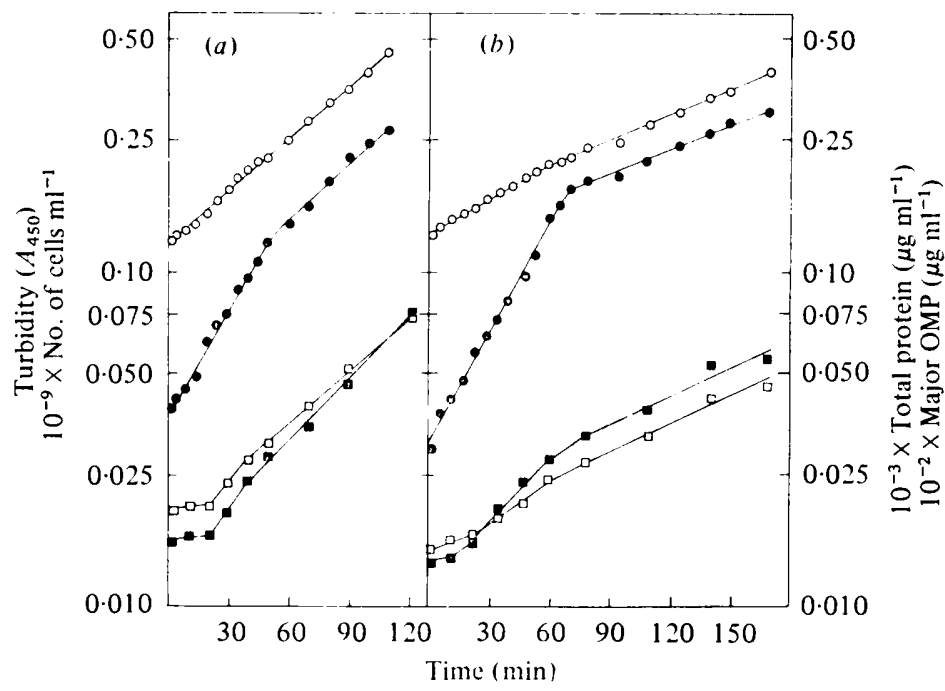

Fig. 5. Effect of shift-down transitions from $\mathrm{LB}$ medium to $(a) \mathrm{AB}$ medium plus $0 \cdot 2 \%(\mathrm{w} / \mathrm{v})$ glucose, or $(b) \mathrm{AB}$ medium plus $0.4 \%(\mathrm{w} / \mathrm{v})$ acetate, on the pattern of cell division and the amount of total cell protein and major OMP. Salmonella typhimurium LT2 was grown exponentially at $37^{\circ} \mathrm{C}$ in LB medium; at time 0 , a sample of cells was filtered, washed with prewarmed medium and resuspended in the original volume of new medium at $37^{\circ} \mathrm{C}$. At intervals samples were taken from the culture and the following measurements were done: $A_{450}(\bigcirc)$, total number of cells per $\mathrm{ml}(\mathbf{O})$, total cell protein per $\mathrm{ml}(\square)$, and major OMP per $\mathrm{ml}(\boldsymbol{\square})$.

The ciose correspondence between the accumulation of total protein and of major OMP during both shift-up transitions (Fig. 3) indicated that the synthesis of major OMP followed the same pattern as that of total protein. As cell dimensions did not follow the same kinetics, there was a transitory uncoupling between the amount of major OMP and cell surface. A plot of the major OMP surface density against time after the shift indicates that the former value did not remain constant (Fig. $4 b$ ). During the abrupt shift from acetate to LB medium, the density of major OMP apparently increased by more than $50 \%$ before reaching the equilibrium value about $80 \mathrm{~min}$ after the shift (this value was about the same as in steady-state conditions). This sharp increase was mainly due to the slow increase in cell dimensions compared with the rapid acceleration in the accumulation of major OMP at around $40 \mathrm{~min}$ after the shift (Fig. $4 b$ ). Only when cell length and diameter reached the final stable value did major OMP density also stabilize.

\section{Changes in major OMP surface density during a shift-down transition}

The effect of a mild (LB to glucose minimal medium) and abrupt (LB to acetate minimal medium) shift-down on the change of cell dimensions and the accumulation of major OMP was also studied. Shift-down transitions are more difficult to interpret than shift-up transitions, because more or less prolonged transitory inhibitions of metabolic processes can occur, which would mask or indirectly influence the phenomena being studied.

Results of a transition from LB to glucose minimal medium are shown in Fig. 5(a). Absorbance and cell number followed a simple pattern. The latter increased initially at a rate characteristic of the former medium and it achieved the rate corresponding to the new medium only after $40 \mathrm{~min}$ from the transition time. Total protein and major OMP accumulated in parallel after a $20 \mathrm{~min}$ lag. Shift-down from LB to acetate minimal medium (Fig. $5 b$ ) showed a slightly different pattern. There was no parallelism between absorbance and cell number until $70 \mathrm{~min}$ after the shift. In contrast to the shift from glucose minimal medium, total protein and major OMP accumulation did not completely stop after the transfer. The reasons for this difference are unknown. 


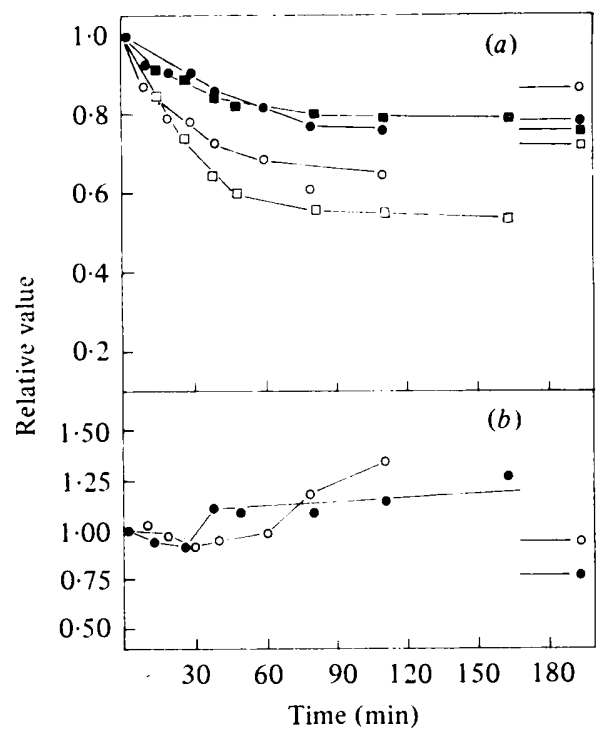

Fig. 6. (a) Changes in cell length $(O, \square)$ and diameter $(O, \square)$ after shift-down transitions of $S$. typhimurium LT2 from LB medium to glucose minimal medium $(O, 0)$ or acetate minimal medium $(\square, \square)$. Transitions were done as described in the legend to Fig. 5 . Relative values of 1.0 correspond to the following absolute values: $\bigcirc, 2.71 \mu \mathrm{m} ; 0,0.736 \mu \mathrm{m} ; \square, 2.65 \mu \mathrm{m} ; \square, 0.743 \mu \mathrm{m}$. (b) Changes in the major OMP per unit of cell surface after shift-down transitions from LB medium to glucose minimal medium $(O)$ or acetate minimal medium (O). Relative values of 1.0 correspond to absolute values of $5.49 \times 10^{-8}$ and $7 \cdot 13 \times 10^{-9} \mu \mathrm{g}$ major OMP per $\mu \mathrm{m}^{2}$ of cell surface, respectively. Bars with the corresponding symbols (on the right) indicate the steady-state levels of the different parameters in the respective media (see Tables 1 and 2).

In contrast to experiments involving shift-up, cell dimensions began to change immediately after the shift-down (Fig. 6a), decreasing to a final cell size in which cells were shorter than in steady-state conditions. The density of major OMP in the surface gradually increased in both shifts, the values eventually reached being higher than those observed during steady-state growth in the same media (Fig. 6b). This may reflect an imbalance between accumulation of major OMP, which is parallel to total protein accumulation, and the smaller cell size attained in these shift-down conditions.

\section{DISCUSSION}

Since the bacterial cell size depends on the growth rate, we have studied both the amount of major OMP in steady-state conditions and its evolution when the envelope area per cell is modified after transition between different media, as an approach to understanding the regulation of major OMP synthesis. The level of major OMP was obtained after analysing total cell lysates by SDS-PAGE. It is known from studies with toluene-treated cells that major OMP are synthesized in the form of a larger precursor which is then processed to the mature form (Sekizawa et al., 1977). However, this precursor does not exist in vivo, so its processing and incorporation into the OM must accompany its synthesis. Therefore, all the major OMP observed in total cell lysates must correspond to molecules incorporated into the OM.

The observed constancy in major OMP surface density supports the idea that the formation of a regular pattern of molecules of these proteins in the $\mathrm{OM}$ is controlled by the amount of surface area available. Although the cross-sections of the major OMP are not known, the calculated number of molecules of major OMP per unit area $\left(0.9 \times 10^{5}\right.$ to 
$1.2 \times 10^{5}$ per $\mu \mathrm{m}^{2}$ ) should imply that a considerable fraction of the $O M$ is covered by major OMP, confirming electron microscope studies (Smit et al., 1975; Steven et al., 1977). It has been shown in $E$. coli $\mathrm{B} / \mathrm{r}$ that the number of lipopolysaccharide (LPS) molecules per unit area increases with growth rate (Zaritsky et al., 1979). No numerical data exist on phospholipids, although Cronan \& Vagelos (1972) reported that the amount of phospholipid with respect to dry weight is constant at different growth rates. As the dry weight per cell increases with growth rate while the ratio of surface area per dry weight decreases (Maaløe \& Kjeldgaard, 1966), the constancy in the proportion of phospholipids should imply an increase in phospholipid surface density with increasing growth rates. These facts suggest that the amount of other OMP should decrease at high growth rates because less physical space should be available. LPS-defective mutants of $S$. typhimurium are known which also have decreased amounts of OMP per unit of surface area, this defect being compensated by an increasing amount of phospholipid (Muhlradt et al., 1974; Smit et al., 1975). Also, some LPS-chain defective mutants increase the number of LPS molecules per area while reducing that of proteins (Gmeiner \& Schlecht, 1979). All these data, therefore, point to a competition between OMP molecules, on the one hand, and LPS and phospholipid, on the other, for the physical space in the OM.

Shift-up and shift-down transitions with the strain employed here showed some differences with respect to other strains. Thus, during the shift-up transitions, cell dimensions began to increase only $20 \mathrm{~min}$ after the shift. Others have reported that cell size increases immediately after the transition (Maaløe \& Kjeldgaard, 1966; Sloan \& Urban, 1976). The discrepancy could be due to differences between strains or between the methods of measuring cell size: we have measured cell dimensions directly from electron micrographs. A delay has also been observed in $E$. coli $\mathrm{B} / \mathrm{r}$ using similar methods to those employed here (Woldringh et al., unpublished observations). The increase in cell dimensions at a particular time after the shift could be due to the increase in the number of sites for envelope growth or to the increase in the rate of accumulation of envelope material into a fixed number of sites. Either of these possibilities raises the question of the cell event that accelerates the growth of the envelope. During steady-state conditions cell elongation seems to be linear with a doubling in rate at a time of the cell cycle (Pritchard, 1974; Donachie et al., 1976; Pierucci, 1978; Rosenberger et al., 1978). It has been proposed that this time is related to the attainment of a critical maximum density (Rosenberger et al., 1978). During the shift-up, cell density probably increases after the transition, because the immediate increase in the rate of absorbance increase is not accompanied by an increase of mean cell volume (Figs 3 and 4). A critical value of density would be achieved after a time, which would induce an increase in the number of sites of envelope growth or in the rate of envelope growth at each site. Interestingly, shortly after the transition to the new medium there is a lag in cell division. This period, which also has been observed in E. coli strains (Loeb et al., 1978), occurs immediately before and after initiation of cell size increase. This is consistent with the idea that formation of cell constrictions leading to division might be due to an excess of envelope produced after doubling of the rate of envelope elongation (Pritchard, 1974; Rosenberger et al., 1978). If bacteria employ the envelope material in increasing both length and width there would be no excess of envelope and no division would occur. Division would resume only after cell density had fallen below a critical level as a consequence of the increase in cell volume.

With respect to major OMP accumulation after shifts, the results show that it follows the same pattern as total cell protein. As the latter does not immediately adjust to changes in cell volume, there is a fluctuation in the ratio of major OMP to cell surface, more pronounced in the shift from acetate minimal medium to LB medium. What happens to the OM structure during the shifts is not known. However, after the shift from acetate minimal medium to LB medium, the density of major OMP increases more than $50 \%$ over the initial and final values. As these proteins can cover more than $60 \%$ of the external OM surface 
(Steven et al., 1977), the above fluctuation can be expected to influence significantly the constitution of the OM. The higher amounts of major proteins after shift-down transitions suggest that in this case also the structure of the OM may differ from that of steady-state grown cells. These differences may result in morphological alterations of the OM not visible in electron micrographs or in parallel changes in the amounts of the other components of the OM.

We thank Drs I. B. Holland and A. Zaritsky for critically reading the manuscript. M.A. is a recipient of a grant from the Spanish Ministry of Universities and Research.

\section{REFERENCES}

Alderman, E. M., Dills, S. S., Melton, T. \& Dobrogosz, W. J. (1979). Cyclic adenosine 3',5'monophosphate regulation of the bacteriophage T6/colicin K receptor of Escherichia coli. Journal of Bacteriology 140, 369-376.

Alphen, W. van \& Lugtenberg, B. (1977). Influence of osmolarity of the growth medium on the outer membrane protein pattern of Escherichia coli. Journal of Bacteriology 131, 623-630.

AmEs, G. F. \& NikaIdo, H. (1976). Two-dimensional gel electrophoresis of membrane proteins. Biochemistry 15, 616-623.

Ames, G. F., Spudich, E. N. \& Nikaido, H. (1974). Protein composition of the outer membrane of Salmonella typhimurium: effect of lipopolysaccharide mutations. Journal of Bacteriology 117, 406-416.

Aono, R., Yamasaki, M. \& Tamura, G. (1978). Changes in composition of envelope proteins in adenylate cyclase- or cyclic AMP receptor protein-deficient mutants of Escherichia coli. Journal of Bacteriology 136, 812-814.

Bassford, P. J., JR, Diedrich, D. L., Schnaitman, C. L. \& ReEves, P. (1977). Outer membrane proteins of Escherichia coli. VI. Protein alteration in bacteriophage-resistant mutants. Journal of Bacteriology 131, 608-622.

BoYD, A. \& Holland, I. B. (1979). Regulation of the synthesis of surface protein in the cell cycle of E. coli $\mathrm{B} / \mathrm{r}$. Cell 18, 287-296.

Bremer, H. \& Dennis, P. P. (1975). Transition period following a nutritional shift-up in the bacterium Escherichia coli $\mathrm{B} / \mathrm{r}$ : stable RNA and protein synthesis. Journal of Theoretical Biology 52, 365-382.

Clark, D. J. \& MaAløe, O. (1967). DNA replication and the division cycle in Escherichia coli. Journal of Molecular Biology 23, 99-112.

Cronan, J. E., JR \& Vagelos, P. R. (1972). Metabolism and function of the membrane phospholipids of Escherichia coli. Biochimica et biophysica acta 265, 25-60.

Datta, D. B., Kramer, C. \& Henning, U. (1976). Diploidy for a structural gene specifying a major protein of the outer cell envelope membrane from Escherichia coli K-12. Journal of Bacteriology 128, 834-841.

DeCaD, G. M. \& Nikaido, H. (1976). Outer membrane of gram-negative bacteria. XII. Molecular sieving function of cell wall. Journal of Bacteriology 128, 325-336.
DenNis, P. P. \& BRemer, H. (1974). Macromolecular composition during steady-state growth of Escherichia coli B/r. Journal of Bacteriology 119 , 270-281.

DiRienzo, J. M., Nakamura, K. \& Inouye, M. (1978). The outer membrane proteins of gramnegative bacteria: biosynthesis, assembly and functions. Annual Review of Biochemistry 47, 481-532.

Donachie, W. D., BegG, K. J. \& Vicente, M. (1976). Cell length, cell growth and cell division. Nature, London 264, 328-333.

Filip, C., Fletcher, G., WulfF, J. L. \& Earhart, C. F. (1973). Solubilization of the cytoplasmic membrane of Escherichia coli by the ionic detergent sodium lauryl sarcosinate. Journal of Bacteriology 115, 717-722.

GMEINER, J. \& SCHLECHT, S. (1979). Molecular organization of the outer membrane of Salmonella typhimurium. European Journal of Biochemistry 93, 609-620.

Grover, N. B., Woldringh, C. L., Zaritsky, A. \& ROSENBERGER, R. F. (1977). Elongation of rodshaped bacteria. Journal of Theoretical Biology 67, 181-193.

Henning, U., Hindennach, I. \& Haller, I. (1976). The major proteins of the Escherichia coli outer cell envelope membrane: evidence for the structural gene of protein II*. FEBS Letters 61, 46-48.

Henning, U., Schmidmayr, W. \& HindennaCH, I. (1977). Major proteins of the outer cell envelope of Escherichia coli K-12: multiple species of protein I. Molecular and General Genetics 154, 293-298.

Kamio, Y. \& Nikaido, H. (1977). Outer membrane of Salmonella typhimurium: identification of proteins exposed on cell surface. Biochimica et biophysica acta 464, 589-601.

KuBITSCHEK, H. E. (1974). Constancy in the ratio of DNA to cell volume in steady state growth of $E$. coli B/r. Biophysical Journal 14, 119-123.

LAEMMLI, U. K. (1970). Cleavage of structural proteins during the assembly of the head of bacteriophage T4. Nature, London 227, 680-685.

Lee, D. R., Schnaitman, C. A. \& Pugsley, A. P. (1979). Chemical heterogeneity of major outer membrane pore proteins of Escherichia coli. Journal of Bacteriology 138, 861-870.

Loeb, A., McGrath, B. E., Navre, J. M. \& Pierucci, O. (1978). Cell division during nutritional upshifts of Escherichia coli. Journal of Bacteriology 136, 631-637. 
Lugtenberg, B., Meijers, J., Peters, R., Hoek, P. VAN DER \& ALPHEN, L. VAN (1975). Electrophoretic resolution of the "major outer membrane protein" of Escherichia coli K12 into four bands. FEBS Letters 58, 254-258.

Lugtenberg, B., Peters, R., Bernheimer, H. \& BERENDSEN, W. (1976). Influence of cultural conditions and mutations on the composition of the outer membrane proteins of Escherichia coli. Molecular and General Genetics 147, 251-262.

MaAløe, O. \& KJeldgaARd, N. O. (1966). Control of Macromolecular Synthesis. New York: Benjamin.

Manning, P. A., Puspurs, A. \& Reeves, P. (1976). Outer membrane of Escherichia coli K-12: isolation of mutants with altered protein $3 \mathrm{~A}$ by using host range mutants of bacteriophage $\mathrm{K} 3$. Journal of Bacteriology 127, 1080-1084.

Muhlradt, P. F., Menzel, J., Goleck, J. R. \& SPETH, V. (1974). Lateral mobility and surface density of lipopolysaccharide in the outer membrane of Salmonella typhimurium. European Journal of Biochemistry 43, 533-539.

NAKAE, T. (1976). Outer membrane of Salmonella. Isolation of protein complex that produces transmembrane channels. Journal of Biological Chemistry 251, 2176-2178.

Nikaido, H. \& NakaE, T. (1979). The outer membrane of gram-negative bacteria. Advances in Microbial Physiology 20, 164-250.

Palva, E. T. (1979). Protein interactions in the outer membrane of Escherichia coli. European Journal of Biochemistry 93, 495-503.

Pedersen, S., Bloch, P. L., Reeh, S. \& Neidhardt, F. (1978). Patterns of protein synthesis in Escherichia coli: a catalogue of the amount of 140 individual proteins at different growth rates. Cell 14, 179-190.

PierucCi, O. (1978). Dimensions of Escherichia coli at various growth rates: model for envelope growth. Journal of Bacteriology 135, 559-574.

Pritchard, R. H. (1974). On the growth and form of a bacterial cell. Philosophical Transactions of the Royal Society B267, 303-336.

Rosenberger, R. F., Grover, N. B., Zaritsky, A. \& Woldringh, C. L. (1978). Control of microbial surface by density. Nature, London 271, 244-245.

RosenbusCH, J. P. (1974). Characterization of the major envelope protein from Escherichia coli. Regular arrangement on the peptidoglycan and unusual dodecyl sulphate binding. Journal of Biological Chemistry 249, 8019-8029.
SATo, T. \& YURA, T. (1979). Chromosomal location and expression of the structural gene for major outer membrane proteins Ia of Escherichia coli K-12 and of the homologous gene of Salmonella typhimurium. Journal of Bacteriology 139, 468-477.

Schaechter, M., MaAløe, O. \& KJeldgaARd, N. O. (1958). Dependency on medium and temperature of cell size and chemical composition during balanced growth of Salmonella typhimurium. Journal of General Microbiology 19, 592-606.

Schmitges, C. J. \& Henning, U. (1976). The major proteins of the Escherichia coli outer cell-envelope membrane. Heterogeneity of protein I. European Journal of Biochemistry 63, 47-52.

Schnaitman, C. (1970). Protein composition of the cell wall and cytoplasmic membrane of Escherichia coli. Journal of Bacteriology 104, 890-901.

Sekizawa, J., Inouye, S., Halegoua, S. \& Inouye, M. (1977). Precursors of major outer membrane proteins of Escherichia coli. Biochemical and Biophysical Research Communications 77, 11261133.

SHeN, V. \& Bremer, H. (1977). Chloramphenicolinduced changes in the synthesis of ribosomal, transfer and messenger ribonucleic acids in Escherichia coli $\mathrm{B} / \mathrm{r}$. Journal of Bacteriology 130, 1098-1108.

Sloan, J. B. \& Urban, J. E. (1976). Growth response of Escherichia coli to nutritional shift-up: immediate division stimulation in slow-growing cells. Journal of Bacteriology 128, 302-308.

Smit, J., Kamio, Y. \& NiKaido, H. (1975). Outer membrane of Salmonella typhimurium: chemical analysis and freeze-fracture studies with lipopolysaccharide mutants. Journal of Bacteriology 124, 942-958.

Steven, A. C., Ten Heggeler, B., Muller, R., Kistler, J. \& Rosenbusch, J. P. (1977). Ultrastructure of a periodic protein layer in the outer membrane of Escherichia coli. Journal of Cell Biology 72, 292-301.

Verhoeff, C., Lugtenberg, B., Boxtel, R. Van, DE GraFF, P. \& VerheiJ, J. (1979). Genetics and biochemistry of the peptidoglycan-associated proteins b and c of Escherichia coli K12. Molecular and General Genetics 169, 137-146.

Zaritsky, A., Woldringh, C. L. \& Mirelman, D. (1979). Constant peptidoglycan density in the sacculus of Escherichia coli $\mathrm{B} / \mathrm{r}$ growing at different rates. FEBS Letters 98, 29-32. 